time and partial thromboplastin time with kaolin indicate severe deficiency of vitamin-K-dependent factors, and this could not have resulted from disseminated intravascular coagulation because there was no deficiency of platelets or fibrinogen and no abnormal fibrinolysis. Though factors $V$ and VIII were not tested, deficiencies can be excluded; they cannot have resulted from genetic or hepatic disorders, because of the duration and timing of the clotting defect, nor from consumption coagulopathy. The nature of the clotting disorder and response to treatment with vitamin $K_{1}$, even though blood was also given, make the diagnosis of vitamin $\mathrm{K}$ deficiency certain.

The mother had a normal prothrombin time two days after delivery, and other screening tests at six weeks showed no clotting defect.

\section{Comment}

This baby developed a subaponeurotic haematoma almost certainly due to the sutures causing or adding to vascular damage beneath the aponeurosis and sealing the stab sites. However, the bleeding began in labour, and the point is made that haemorrhagic disease can occur early enough to complicate fetal blood sampling. Though major complications of this procedure are rare fatal exsanguination in labour has been reported (Saling, 1965; Beard et al., 1966), but adequate clotting tests were not possible in these cases. This baby luckily delivered soon after the blood sampling and yet nearly died because the diagnosis was not suspected. Earlier prophylactic infusion of fresh frozen plasma (Ahuja et al., 1969) and reliance on local pressure rather than sutures to control the bleeding might have prevented such serious complication. The total dose of vitamin $K_{1}$ given in this case was much more than necessary, and $1 \mathrm{mg}$ should always suffice.

A huge volume of blood can collect under the aponeurosis before it is noticed because of the symmetry and even distribution of the swelling. The possibility that much of this blood might be reabsorbed intact into the circulation was suggested by Robinson and Rossiter (1968) and is supported in this case by the rise in haemoglobin concentration that continued after transfusion and by the absence of jaundice.

We are indebted to Dr. P. J. N. Cox and Mr. A. C. Fraser for their kind permission to report this case, and to the Royal Society of Medicine, where it was first presented on 25 June 1971.

\section{References}

Ahuja, G. L., Willoughby, M. L. N., Kerr, Margaret M., and Hutchison, J. H. (1969). British Medical fournal, 3, 743.

Beard, R. W., Morris, E. D., and Clayton, S. G. (1966). Fournal of Obstetrics and Gynaecology of the British Commonwealth, 73, 860. British Medical fournal, 1971, 4 , 1 .

British Medical fournal, 1971, 4, 1. (1968). Archives of Disease in Childhood, 43, 684

Saling, F. (1965). fournal of the International Federation of Gynaecology and Obstetrics, 3, 100.

\title{
Changes in Human Drug Metabolism after Long-term Exposure to Hypnotics
}

\author{
I. H. STEVENSON, MARGARET BROWNING, J. CROOKS, K. O'MALLEY
}

British Medical fournal, 1972, 4, 322-324

\section{Summary}

The influence of the newer, non-barbiturate hypnotics Mandrax (diphenhydramine-methaqualone) and nitrazepam on drug-metabolizing capacity was assessed and compared with the effect of amylobarbitone, a known inducer of drug-metabolizing enzymes. Plasma antipyrine and phenylbutazone half-lives and urinary output of $6 \beta$-hydroxycortisol were used as indices. Volunteer subjects were exposed to therapeutic amounts of these agents and, in the case of Mandrax and barbiturates, further studies were carried out in dependent patients.

Mandrax but not nitrazepam increased the rate of drug metabolism, presumably by enzyme induction. The degree of induction was comparable with that produced by hypnotic doses of amylobarbitone. The Mandraxdependent and barbiturate-dependent patients were the fastest metabolizers studied. It is concluded that drug interactions resulting from interference with drug metabolism are as likely to occur with Mandrax as with barbiturates. On the other hand, it is unlikely that such drug interactions would occur with nitrazepam.

\footnotetext{
Departments of Pharmacology and Therapeutics and Clinical Chemistry, Dundee University, Dundee

I. H. STEVENSON, B.SC., PH.D., Senior Lecturer MARGARET BROWNING, B.SC., Senior Biochemist

J. CROOKS, M.D., F.R.C.P., Professor

K. O'MALLEY, M.D., M.R.C.P.I., Research Fellow
}

\section{Introduction}

As a group, hypnotic drugs are among the most widely used and are frequently prescribed in combination with other drugs. Since they may cause alteration in protein binding and in rate of metabolism of concurrently administered therapeutic agents, it is not surprising that there have been many reports of drug interactions occurring with this group (Hansten, 1971). With glutethimide, and to a greater extent with the barbiturates, the effects on drug metabolism are well documented (MacDonald et al., 1969). Similarly, alteration in protein binding with chloral hydrate administration has been much studied (Sellars and Koch-Weser, 1971). In the present study we have examined the effects on drug metabolism of therapeutic doses of two of the newer, widely-used, non-barbiturate hypnotics, nitrazepam and Mandrax, together with the constituents of the latter, methaqualone and diphenhydramine. For comparison, we have also studied the effect of hypnotic doses of amylobarbitone, and in addition have measured the rate of drug metabolism in a few patients dependent on Mandrax or barbiturates. So far as we are aware, no formal assessment of the effects of these nonbarbiturate hypnotics on human drug-metabolizing capacity has previously been made. However, in a recent study carried out in animals we have found Mandrax to have a potent inducing effect on liver microsomal enzymes, whereas nitrazepam even in high dose produced only a weak stimulation (Ballinger et al., 1971).

In this investigation we have used plasma phenazone (antipyrine) and phenylbutazone (Butazolidin) half-life values together with urinary output of $6 \beta$-hydroxycortisol as indices of drug-metabolizing capacity. Both test drugs are extensively 
metabolized in the liver (Brodie and Axelrod, 1950; Burns et al., 1953). Antipyrine is minimally protein bound (Soberman et al., 1949) and its rate of elimination from the plasma reflects its rate of metabolism. Phenylbutazone is a convenient example of a highly protein-bound drug which is metabolized before excretion (Burns et al., 1953). The 6 $\beta$-hydroxylation of cortisol requires the same microsomal enzyme system as is involved in hydroxylation of drugs. Inducers of drug metabolism are known to increase the urinary output of $6 \beta$-hydroxycortisol (Conney et al., 1965).

\section{Subjects and Methods}

Medical students, university, and hospital personnel in the age range 18-52 years and to whom the study had been fully explained took part. So far as could be ascertained none of the subjects had taken any drug during the previous two months. All subjects maintained their usual consumption of tobacco and alcohol throughout the study.

Subjects took one of the following drugs nightly for a threeweek period: amylobarbitone (Amytal, $200 \mathrm{mg}$ ), nitrazepam (Mogadon 5 or $10 \mathrm{mg}$ ), Mandrax (275 or $500 \mathrm{mg}$ ), methaqualone (Melsed 250 or $500 \mathrm{mg}$ ), diphenhydramine (Benadryl $50 \mathrm{mg}$ ). Where subjects experienced side effects the lower dose was used.

The criteria for inclusion of Mandrax-dependent and barbiturate-dependent patients were as previously described (Ballinger, et al., 1972), the antipyrine test being carried out while patients were on full drug dose. Informed consent was obtained from all patients participating in the study.

Antipyrine $(18 \mathrm{mg} / \mathrm{kg})$ was given in aqueous solution and four plasma samples were taken at about three-hourly intervals thereafter. Phenylbutazone (Butazolidin, $6 \mathrm{mg} / \mathrm{kg}$ ) was given in tablet form and four blood samples were taken over the next four days. Antipyrine was estimated by the method of Brodie et al. (1949) and phenylbutazone by the method of Burns et al. (1953). For 6 $\beta$-hydroxycortisol and 17-hydroxycorticosteroid determinations single 24-hour urine collections were made and estimations carried out by the method of Thrasher et al. (1969) and Few (1961) respectively. Antipyrine and $6 \beta$-hydroxycortisol assays were carried out before and after the period of drug treatment, the last hypnotic dose being about 10 hours before taking the test drug or the start of urine collection. With phenylbutazone, hypnotic therapy was continued throughout the period of sampling. With each of the five preparations studied different groups of subjects were used for the antipyrine and phenylbutazone assessments except in the case of nine Mandrax subjects in whom both antipyrine and phenylbutazone half-life determinations were made, the phenylbutazone being given 48 hours after the antipyrine.

Statistical Analysis.-Intraindividual differences occurring after hypnotic treatment (Tables I and II) were analysed statistically using the $t$ test for paired observations. In the drugdependent patients (Table III) comparison with controls was made using Student's $t$ test.

\section{Results}

Plasma antipyrine and phenylbutazone half-life values obtained before and after three week's exposure to each of the five drugs are shown in Table I. No alteration in volume of distribution of the two test drugs occurred after hypnotic treatment. Significant reduction of antipyrine half-life occurred with amylobarbitone (35\%) and Mandrax (27\%). With this index no significant change occurred after treatment with nitrazepam or the constituents of Mandrax. With phenylbutazone as the test drug, no significant change occurred with any of the five drugs studied. Although Mandrax, methaqualone, and diphenhydramine separately reduced plasma phenylbutazone half-life by $18 \%$, $15 \%$, and $14 \%$ respectively, these differences were not statistically significant $(P>0.05)$.

In the nine subjects in whom both test drug half-lives were determined before and after Mandrax there was a significant positive correlation between the changes occurring with these two indices (see Chart). After amylobarbitone or Mandrax treatment there was an increase in urinary $6 \beta$-hydroxycortisol output, both in absolute amounts (amylobarbitone $56 \%$, Mandrax 38\%) and when expressed as a ratio to total urinary 17-hydroxycorticosteroid (Table II). Nitrazepam treatment had no effect on the output of these steroids.

In the Mandrax-dependent and barbiturate-dependent patients the plasma antipyrine half-life values were similar and were very much lower than in either drug-free control subjects

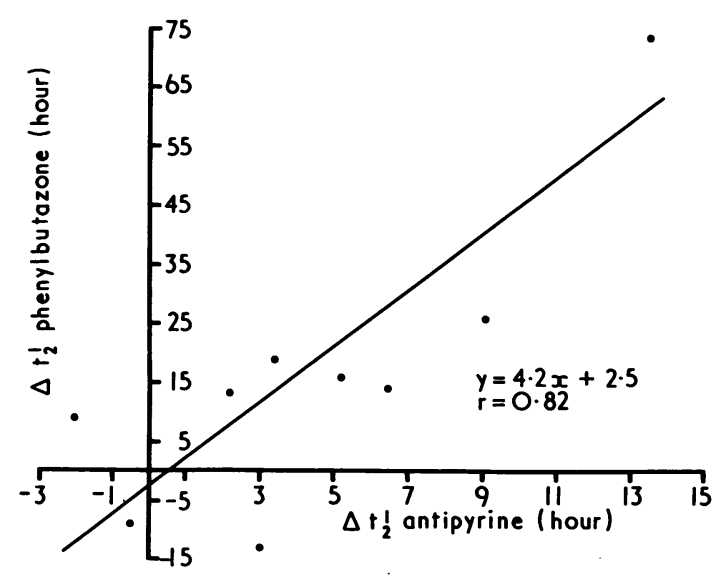

Change in antipyrine and phenylbutazone half-life after Mandrax treatment in nine subjects.

TABLE I-Effect of Hypnotic Treatment on Plasma Antipyrine and Phenylbutazone Half-lives (Mean \pm S.D.)

\begin{tabular}{|c|c|c|c|c|c|c|c|c|}
\hline \multirow{2}{*}{\multicolumn{3}{|c|}{ Drug }} & \multirow{2}{*}{$\begin{array}{c}\text { No. } \\
\text { of } \\
\text { Subjects }\end{array}$} & \multicolumn{2}{|c|}{ Antipyrine Half-life } & \multirow{2}{*}{$\begin{array}{c}\text { No. } \\
\text { of } \\
\text { Subjects }\end{array}$} & \multicolumn{2}{|c|}{ Phenylbutazone Half-life } \\
\hline & & & & Before & After & & Before & After \\
\hline $\begin{array}{l}\text { Amylobarbitone } \\
\text { Nitrazepam } \quad . \\
\text { Mandrax } \\
\text { Methaqualone } \\
\text { Diphenhydramine }\end{array}$ & $\begin{array}{l}. \\
\therefore \\
\therefore\end{array}$ & $\begin{array}{l}\because \\
\therefore \\
\therefore \\
\therefore\end{array}$ & $\begin{array}{r}19 \\
10 \\
14 \\
6 \\
9\end{array}$ & $\begin{array}{l}12.1 \pm 3.3 \\
12.6 \pm 2.3 \\
14.8 \pm 4.6 \\
13.2 \pm 5.7 \\
11.0 \pm 3.8\end{array}$ & $\begin{aligned} 7.8 & \pm 1.9 * \\
14.4 \pm & 2.4 \\
10.8 & \pm .2 * \\
12.0 & \pm .8 \\
11.9 & \pm .5\end{aligned}$ & $\begin{array}{r}6 \\
7 \\
10 \\
7 \\
6\end{array}$ & $\begin{array}{l}59.7 \pm 25.9 \\
92.0 \pm 23.8 \\
89.7 \pm 29.9 \\
75.2 \pm 16.4 \\
79.2 \pm 23.7\end{array}$ & $\begin{array}{ll}63.2 & \pm 20.3 \\
94.4 & \pm 28.4 \\
73.9 & 11 \cdot 3 \\
64.3 & 9.5 \\
68.0 & \pm 13.3\end{array}$ \\
\hline
\end{tabular}

$* \mathbf{P}<0.05$.

TABLE II-Effect of Hypnotic Treatment on Urinary Steroid Excretion (Mean \pm S.D.)

\begin{tabular}{|c|c|c|c|c|c|c|c|}
\hline \multicolumn{3}{|c|}{ Drug } & \multirow{2}{*}{$\begin{array}{c}\begin{array}{c}\text { No. of } \\
\text { Subjects }\end{array} \\
5 \\
14\end{array}$} & \multicolumn{2}{|c|}{$\begin{array}{c}\text { 6ß-Hydroxycortisol } \\
(\mathrm{mg} / 24 \mathrm{hr})\end{array}$} & \multirow{2}{*}{$\begin{array}{c}\begin{array}{c}\text { 17-Hydroxycorticosteroids } \\
(\mathrm{mg} / 24 \mathrm{hr})\end{array} \\
11.4 \pm 4.2 \\
9.7 \pm 2.9 \\
9.6 \pm 3.3 \\
9.6 \pm 3.4 \\
11.0 \pm 3.5 \\
11.4 \pm 3.5\end{array}$} & \multirow{2}{*}{ 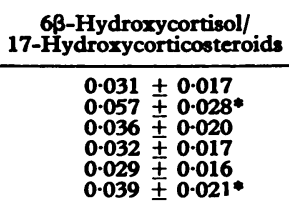 } \\
\hline $\begin{array}{l}\text { Amylobarbiton } \\
\text { Nitrazepam } \\
\text { Mandrax }\end{array}$ & $\begin{array}{l}\cdots \\
\cdots \\
\ldots\end{array}$ & $\begin{array}{l}\cdots \\
\cdots \\
\cdots\end{array}$ & & $\left\{\begin{array}{l}\text { Before } \\
\text { After } \\
\text { Before } \\
\text { After } \\
\text { Before } \\
\text { After }\end{array}\right.$ & $\begin{array}{l}0.32 \pm 0.13 \\
0.50 \pm 0.17 \\
0.32 \pm 0.16 \\
0.28 \pm 0.14 \\
0.32 \pm 0.10 \\
0.44 \pm 0.12 \dagger\end{array}$ & & \\
\hline
\end{tabular}

${ }^{*} \mathrm{P}<0.05 .+\mathrm{P}<0.02$. 
(Mandrax $52 \%$, barbiturate $44 \%$ of control values) or in subjects taking therapeutic doses of these hypnotics (Table III).

TABLE III-Plasma Antipyrine Half-life in Hypnotic-dependent Groups (Mean \pm S.D.)

\begin{tabular}{|c|c|c|c|c|c|}
\hline & & & $\begin{array}{l}\text { No. of } \\
\text { Subjects }\end{array}$ & \multicolumn{2}{|c|}{$\begin{array}{l}\text { Plasma Antipyrine } \\
\text { Half-life (hr) }\end{array}$} \\
\hline $\begin{array}{l}\text { Control (no drug } \\
\text { Barbiturate-depee } \\
\text { Mandrax-depend } \\
\end{array}$ & $\begin{array}{l}\text { s) } \\
\text { ndent } \\
\text { lent }\end{array}$ & $\begin{array}{l}\cdots \\
\therefore \\
.\end{array}$ & $\begin{array}{r}61 \\
8 \\
3 \\
\end{array}$ & \multicolumn{2}{|r|}{$\begin{aligned} & 12.0 \pm 3.5 \\
& 5.3 \pm 1.2(P<0.001) \\
& 6.2 \pm 2.0(P<0.01)\end{aligned}$} \\
\hline \multirow{2}{*}{\multicolumn{3}{|c|}{$\begin{array}{l}\text { Amylobarbitone } \\
\text { Mandrax }\end{array}\left\{\begin{array}{l}\text { Hypnotic } \\
\text { dose for } \\
3 \text { weeks }\end{array}\right.$}} & \multirow[b]{2}{*}{$\begin{array}{l}19 \\
14\end{array}$} & Before & After \\
\hline & & & & 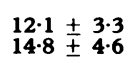 & $\begin{array}{r}7.8 \pm 1.9(P<0.05) \\
10.8 \pm 3.2(P<0.005)\end{array}$ \\
\hline
\end{tabular}

\section{Discussion}

The objective of the present study was to assess whether the newer non-barbiturate hypnotics are as likely as barbiturates to interfere with drug-metabolizing processes and consequently to alter the rate of metabolism of concomitantly administered drugs. With two of the three indices studied-that is, plasma antipyrine half-life (Table I) and urinary output of $6 \beta$-hydroxycortisol (Table II)-our findings suggest that both Mandrax and amylobarbitone brought about significant stimulation of drug-metabolizing capacity. With nitrazepam there was no evidence of interference with drug metabolism with any of the three indices used. The particularly short antipyrine half-lives in the Mandrax-dependent and barbituratedependent patients (Table III) indicates a pronounced degree of induction in these situations. These results obtained with Mandrax and nitrazepam are in agreement with our previous report of their effects on rat liver microsomal drug metabolism (Ballinger et al., 1971). There was no significant change in test drug half-life with diphenhydramine or methaqualone, the constituents of Mandrax. Although the groups studied were small, the slightly shorter plasma half-lives with both test drugs after methaqualone treatment suggests, however, that this component may be the main contributor to the induction produced by Mandrax (Tables I and II).

The test drug most frequently used in this investigationthat is, antipyrine-is being increasingly used as an index of drug-metabolizing capacity in man. In a number of investigations plasma antipyrine half-life has been shown to change as expected after treatment with drugs which are known from animal studies to be inducers or inhibitors of microsomal drugmetabolizing enzymes (Kolmodin et al., 1969; Kampffmeyer, 1971 ; Vesell et al., 1971). It seems likely, therefore, that changes in antipyrine half-life in man reflect alterations in drugmetabolizing capacity. Similarly, urinary output of $6 \beta$-hydroxycortisol has been shown to be increased in subjects exposed to "enzyme inducers" such as phenobarbitone (Brooks et al., 1972), diphenylhydantoin (Werk et al., 1964), and DDT (Poland et al., 1970). The increased urinary output of $6 \beta-$ hydroxycortisol after Mandrax treatment therefore provides further evidence that induction occurs with this drug. In the nine subjects in whom both antipyrine and phenylbutazone assessments were carried out before and after Mandrax treatment there was a positive correlation between the changes occurring in the two indices (Chart). The lack of significant change in phenylbutazone half-life, considered alone, after treatment with any of the drugs studied is interesting. Phenobarbitone treatment has been shown to reduce the half-life of antipyrine by $40 \%$ (Kampffmeyer, 1971) but the half-life of phenylbutazone is reduced by only $10 \%$ in the same circumstances (Whittaker and Price-Evans, 1970). Also, while the half-life of antipyrine in subjects exposed to DDT has been shown to be reduced by $32 \%$ that of phenylbutazone was reduced by only $19 \%$ (Kolmodin et al., 1969; Poland et al., 1970). Similarly, in a study of the effects of oral contraceptive steroids on drug metabolism (O'Malley et al., 1972) the increase in plasma antipyrine half-life was about twice that found with phenylbutazone. This evidence suggests that change in phenylbutazone half-life may be a less sensitive index of changes in drug-metabolizing capacity in man. Lack of significant alteration in phenylbutazone half-life may therefore not exclude the possibility of alteration in capacity to metabolize other drugs.

The present results with antipyrine and $6 \beta$-hydroxycortisol as indices of drug-metabolizing capacity suggest that Mandrax but not nitrazepam may bring about induction of microsomal enzyme activity in man. The degree of induction was similar to that produced by treatment with amylobarbitone. We suggest, therefore, that the adverse drug reactions which are known to occur with barbiturates as a result of their enhancing the metabolism of concomitantly administered drugs are as likely to occur with Mandrax. This would seem unlikely to occur with nitrazepam, however. Also patients taking these hypnotics may have different requirements for other drugs. The oral anticoagulant requirement, for example, is high in patients taking amylobarbitone, and there is evidence from studies in two patients that it is unchanged with nitrazepam (Breckenridge and Orme, 1971). Our results suggest that patients taking Mandrax would also have a high requirement for oral anticoagulants. In order to verify this and to extend the data on nitrazepam we are at present carrying out an epidemiological study using a hospital-based drug information system (Coull et al., 1970) to determine oral anticoagulant requirements in patients taking these hypnotics.

We wish to thank the Medical Research Council for financial support, and Messrs. Roche Products Ltd. for supply of nitrazecam. We gratefully acknowledge the technical help of Mrs. W. Alexander and Mrs. M. West, and the co-operation of the subjects who participated in the study.

\section{References}

Ballinger, B., Browning, M., O'Malley, K., and Stevenson, I. H. (1972). British fournal of Pharmacology. 45, 638 .

Ballinger, B. R., O'Malley, K., Stevenson, I. H., and Turnbull, M. J. (1971). British fournal of Pharmacology, 41, 383P.

Breckenridge, A., and Orme, M. (1971). Annals of the New York Academy of Sciences, 179, 421.

Brodie, B. B., and Axelrod, J. (1950). Fournal of Pharmacology and Experimental Therapeutics, 98, 97.

mental Therapeutics, 98, 97.
Brodie, B. B., Axelrod, J., Soberman, P., and Levy, B. B. (1949). Fournal of Biological Chemistry, 179, 25.

Brooks, S. M., Werk, E. E., Ackerman, S. J., Sullivan, I., and Thrasher, K. (1972). New England fournal of Medicine, 286, 1125.

Burns, J. J., et al. (1953). Fournal of Pharmacology and Experimental Therapeutics, $109,346$.

Conney, A. H., Jacobson, M., Schneidman, K., and Kuntzman, R. (1965). Life Sciences, 4, 1091.

Coull, D. C., Crooks, J., Davidson, J. F., Gallon, S. C., and Weir, R. D. (1970). European fournal of Clinical Pharmacology, 3, 46.

Few, J. D. (1961). Fournal of Endocrinology, 22, 31.
Hansten, P. D. (1971). Drug Interactions. Philadelphia, Lea \& Febiger.

Kampfimeyer, H. G. (1971). European fournal of Clinical Pharmacology, 3, 113 . 3, 113.
Kolmodin, B., Azarnoff, D. L., and Sjoqvist, F. (1969). Clinical Pharmacology
and Therapeutics, 10, 638.

MacDonald, M. G., Robinson, D. S., Sylvester, D., and Jaffe, J. (1969). Clinical Pharmacology and Therapeutics, 10, 80

O'Malley, K., Stevenson, I. H., and Crooks, J. (1972). Clinical Pharmacology and Therapeutics. 13, 552.

Poland, A., Smith, D., Kuntzman, R., Jacobson, M., and Conney, A. H. (1970). Clinical Pharmacology and Therapeutics, 11, 724.

Sellars, E. M., and Koch-Weser, J. (1971). Annals of the New York Academy of Sciences, 179, 213.

Soberman, R., et al. (1949). Fournal of Biological Chemistry, 179, 31.

Thrasher, K., et al. (1969). Steroids, 14, 455.

Vesell, E. S., Ng, L., Passananti, G. T., and Chase, T. N. (1971). Lancet,

Werk, E. E., MacGee, J., and Sholiton, L. J. (1964). Fournal of Clinical Investigation, 43, 1824 .

Whittaker, J. A., and Price-Evans, D. A. (1970). British Medical fournal, 4, 323. 